\title{
Integrasi Kearifan Lokal Pada Pembelajaran di SD Melalui Etnomatematika dan Etnosains (Ethnomathscience)
}

\author{
Ratna Widyaningrum*1, Ema Butsi Prihastari² \\ 1,2 Program Studi Pendidikan Guru Sekolah Dasar, Fakultas Keguruan dan Ilmu Pendidikan, Universitas \\ Slamet Riyadi \\ *e-mail: ratnawidya133@gmail.com ${ }^{1}$, butsinegara@gmail.com²
}

\begin{abstract}
Based on an international survey, the performance of Indonesian students in mathematics and science is relatively low. So learning innovations are needed for enjoyable learning. Etnomathscience is a collaboration between ethnomathematics and ethnoscience so that local culture is integrated synergistically in learning. The achieved from this program are providing: 1) an understanding of Ethnomathscience, 2) skills for teachers in analyzing teaching material that can be integrated with the local culture. This service was carried out at SDN Prawit I Surakarta. The methods of service delivery include approach methods starting from the survey, licensing, and motivation; the implementation of the program including the preliminary stage, the stage of socialization and audience, the implementation phase, and the evaluation phase. The target is the participants can understand and can be integrated ethnomathscience in learning and have the skills in analyzing teaching material that can be integrated with the environment and local culture.
\end{abstract}

Keywords: local culture, primary school learning, ethnomathscience

\begin{abstract}
Abstrak
Berdasarkan hasil survei internasional performa peserta didik di Indonesia pada bidang matematika dan sains masih tergolong rendah. Oleh karena itu, kehadiran inovasi pembelajaran sangat diperlukan agar pembelajaran lebih menyenangkan. Salah satunya adalah dengan mengaitkan budaya lokal dalam pembelajaran. Ethnomathscience merupakan kolaborasi antara etnomatematika dan etnosains, sehingga budaya lokal diintegrasikan secara sinergis. Tujuan dari program ini adalah 1) memberikan pemahaman tentang ehtnomathscience, 2) memberikan keterampilan bagi guru dalam menganalisis materi ajar yang dapat diintegrasikan dengan budaya lokal kota Surakarta. Pengabdian ini dilakukan di SDN Prawit I Surakarta. Metode pelaksanaan pengabdian meliputi metode pendekatan mulai tahap survei, perijinan, dan pemberian motivasi bagi guru metode pelaksanaan program meliputi tahap pendahuluan, tahap sosialisasi dan audiensi, tahap pelaksanaan, serta tahap evaluasi. Target yang diharapkan adalah guru memahami dan mampu mengintegrasikan ethnomathscience dalam pembelajaran dalam bentuk bahan ajar, serta memiliki keterampilan dalam menganalisis materi ajar yang dapat diintegrasikan dengan lingkungan dan budaya lokal.
\end{abstract}

Kata kunci: budaya lokal, pembelajaran di SD, etnomathscience

\section{PENDAHULUAN}

Pelaksanaan kegiatan belajar mengajar di sekolah berpedoman pada kurikulum sebagai arah rencana pendidikan. Kurikulum di Indonesia telah mengalami beberapa kali perubahan dan perbaikan. Perubahan kurikulum dilakukan seiring dengan perkembangan dan kemajuan zaman agar tujuan pendidikan mencapai hasil yang maksimal. Sejak tahun ajaran 2012/2013, pemerintah melalui Kemendikbud menerapkan pendidikan dengan diberlakukannya Kurikulum 2013 di setiap jenjang pendidikan. Kurikulum 2013 menekankan pembelajaran yang memotivasi siswa untuk berpartisipasi secara aktif agar mampu mengembangkan kreativitas dan kemandirian siswa sesuai dengan bakat dan minat.

Sekolah Dasar (SD) sebagai lembaga pendidikan dasar yang mejadi fondasi awal untuk memberikan pengetahuan, menanamkan nilai-nilai karakter, dan memberikan keterampilan pada siswa. Namun, kondisi saat ini menunjukkan bahwa siswa di Indonesia masih lemah dalam hal pembelajaran Matematika dan Sains. Hal tersebut dapat diketahui dari hasil survei Programme for International Students Assesment (PISA) tahun 2016, menunjukkan bahwa performa siswasiswi Indonesia dalam rata-rata pencapaian skor untuk sains pada peringkat 62 , literasi pada 
peringkat 61, dan matematika pada peringkat 63 dari 69 negara yang dievaluasi (Kemendikbud, 2016). Hal tersebut dapat dijadikan suatu gambaran bahwa kualitas pendidikan di Indonesia harus ditingkatkan agar tidak tertinggal dengan negara-negara lain. Pendidikan di Indonesia tentunya harus disesuaikan dengan tuntutan keterampilan abad XXI antara lain penguasaan literasi dasar (Sains, Matematika, membaca, dan teknologi), kecakapan berpikir kritis, kreatif, komunikasi, kolaborasi, dan karakter. Berdasarkan fakta yang ada di lapangan maka diperlukan penguatan pembelajaran dalam bidang Matematika dan IPA di sekolah dasar.

Salah satu upaya yang dapat dilakukan adalah mengaitkan lingkungan dan budaya lokal dalam pembelajaran. Budaya adalah pikiran, akal budi, adat istiadat sedangkan kebudayaan adalah hasil kegiatan dan penciptaan batin (akal budi) manusia, seperti kepercayaan, kesenian dan adat istiadat (Wahyuni, Aji, Tias, \& Sani, 2013). Lingkup budaya, dimensi fisik dari kearifan lokal meliputi aspek : (1) Upacara Adat, (2) Cagar Budaya, (3) Pariwisata-Alam, (4) Transportasi tradisional, (5) Permainan tradisional, (6) Prasarana budaya, (7) Pakaian adat, (8) Warisan budaya, (9) Museum, (10) Lembaga budaya, (11) Kesenian, (12) Desa budaya, (13) Kesenian dan kerajinan, (14) Cerita rakyat, (15) Dolanan anak, dan (16) Wayang (Wagiran, 2011). Kearifan lokal biasanya tercermin dalam kebiasaan-kebiasaan hidup masyarakat yang telah berlangsung lama. Keberlangsungan kearifan lokal akan tercermin dalam nilai-nilai yang berlaku dalam kelompok masyarakat tertentu. Nilainilai itu menjadi pegangan kelompok masyarakat tertentu yang biasanya menjadi bagian hidup tak terpisahkan yang dapat diamati melalui sikap dan perilaku sehari-hari (Ambalegin, Arianto, \& Azharman, 2019).

Pembelajaran berbasis budaya pada jenjang pendidikan dasar merupakan suatu alternatif pendekatan pembelajaran yang mengutamakan aktivitas peserta didik dengan berbagai latar belakang budaya yang dimiliki. Etnomatematika dan etnosains merupakan salah satu dari wujud pendidikan berbasis budaya, yang selanjutnya akan dikolaborasikan menjadi etnomathscience. Etno menggambarkan semua hal yang membentuk identitas budaya suatu kelompok, yaitu bahasa, kode, nilai-nilai, jargon, keyakinan, makanan dan pakaian, kebiasaan, dan sifat-sifat fisik. Sedangkan matematika mencakup pandangan yang luas mengenai aritmetika, mengklasifikasikan, mengurutkan, menyimpulkan, dan modeling. Etnomatematika adalah suatu ilmu yang digunakan untuk memahami bagaimana matematika diadaptasi dari sebuah budaya (Sunandar, 2012).

Istilah ethnoscience berasal dari kata ethos dari bahasa Yunani yang berarti 'bangsa' dan kata scientia dari bahasa latin yang berarti pengetahuan. Etnosains kurang lebih berarti pengetahuan yang dimiliki oleh suatu bangsa atau lebih tepat oleh suatu suku bangsa atau kelompok sosial dan sebagai bentuk kearifan lokal (Hadi, Sari, Sugiarto, Mawaddah, \& Arifin., 2019). Etnosains merupakan strategi penciptaan lingkungan belajar dengan mengintegrasikan budaya sebagai bagian dari proses pembelajaran IPA sehingga berguna bagi kehidupannya. Menurut Sudarmin (2015) berbagai jenis kajian etnosains yang berhasil diteliti oleh para ahli antropologi dan bidang sains melahirkan hakikat etnosains, yaitu suatu kebudayaan sebagai sistem pengetahuan, yang berupa (a) klasifikasi-klasifikasi lewat bahasa lokal atau istilah lokal dan kategori budaya lokal, (b) aturan atau nilai-nilai moral berdasarkan kategori budaya lokal, (c) pelukisan sistem pengetahuan asli(indegenous Science) yang terdapat pada budaya warga masyarakat atau kelompok masyarakat tertentu (Hadi, Sari, Sugiarto, Mawaddah, \& Arifin, 2019).

Etnomathscience dalam pengabdian ini dimaksudakan untuk mengkolaborasi antara budaya Surakarta dengan pembelajaran matematika dan IPA. Kearifan lokal yang disampaikan saat kegiatan pengabdian kepada masyarakat berkaitan erat antara lain: batik Laweyan, Pasar Gede, tanaman obat sebagai bahan baku jamu, tataguna lahan dan pola bercocok tanam dan musim (Widyaningrum, 2018). Adanya pemetaan lokasi dan tema diharapkan mempermudah guru dalam menganalisis materi ajar atau bahan ajar yang sesuai agar dapat diintegrasikan dalam pembelajaran tematik di kurikulum 2013. Tujuan yang hendak dicapai dari program ini adalah memberikan pemahaman berkaitan dengan etnomatematika dan etnosains (ethnomathscience) serta memberikan keterampilan bagi guru dalam menganalisis materi ajar yang dapat 
diintegrasikan dengan budaya lokal kota Surakarta. Pemetaan materi budaya lokal dalam pembelajaran Matematika dan IPA dapat dilihat pada Tabel 1 berikut.

Tabel 1. Pemetaan budaya Surakarta yang diintegrasikan dengan materi Matematika dan IPA

\begin{tabular}{llc}
\hline No & Kearifan Lokal & Materi Matematika \\
1. & Batik Laweyan & $\begin{array}{l}\text { Geometri bangun datar (materi } \\
\text { kelas 3 Tema 4) } \\
\end{array}$ \\
&
\end{tabular}

Gambar 1. Motif batik slobog

Motif Slobog dominan pada kumpulan bidang datar, diantaranya segitiga (sama kaki), persegi panjang, belah ketupat, dan persegi. Jenis segitiga dapat dilihat berdasarkan panjang sisi dan besar sudut.
Materi IPA

Pencemaran lingkungan yang mempengaruhi kualitas air dan cara pengolahan limbah batik. (Materi kelas 5 tema 8)

Limbah sisa batik (malam) yang sudah tidak terpakai bisa di olah lagi dan diberi campuran yang lain agar menjadi malam yang siap digunakan untuk proses pembuatan batik selanjutnya. Terdapat bak penampungan untuk limbah batik, sehingga limbah dari lilin diproses ulang seddangkan limbah pewarnanya biasanya disaring lalu dtampung di bak penampungan sampai mengendap, baru dialirkan ke selokan.
2. Pasar Gede

3. Tanaman Obat sebagai bahan pembuatan jamu
Besaran (materi kelas 3 tema 1) dan Jual beli (materi kelas 5 tema 2)

Beberapa bagian yang ada di bangunan pintu masuk dari Pasar Gedhe menyerupai beberapa bidang datar. Seperti bagian atap, jendela, dari bangunan pintu masuk Pasar menyerupai trapesium, lubang angin yang berbentuk lingkaran, jendela yang berbentuk persegi panjang.

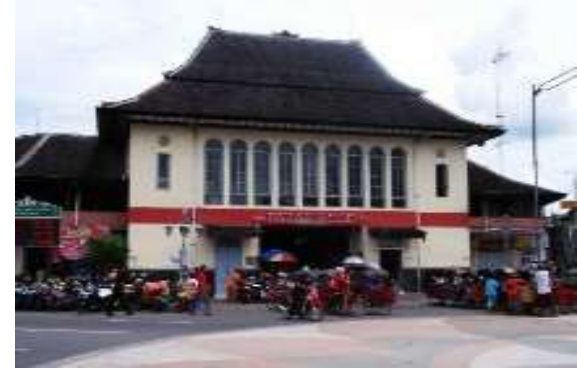

Gambar 2. Arsitektur Pasar Gedhe
Makanan dan Kesehatan (Materi Kelas 5 Tema 3)

Komoditas yang dijual di pasar gede dapat dikaitkan dengan makanan dan kesehatan. Kandungan makanan mulai dari karbohidrat, protein, lemak, vitamin, mineral, dan air. Selain itu dapat dikaitkan dengan ciri makanan sehat dan tidak sehat, dan penggunaan zat pewana dan pemanis dalam makanan

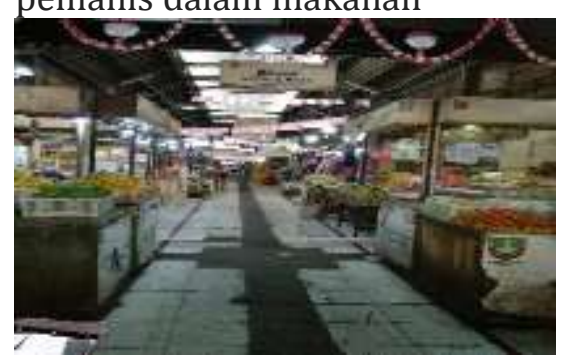

Gambar 3. Salah satu komoditas di Pasar Gedhe

Perkembang biakan pada tumbuhan (Materi kelas 3 Tema 1 subtema 2)

Macam-macam tanaman obat dapat dikaitkan dengan 


\begin{tabular}{|c|c|c|c|}
\hline & & $\begin{array}{l}\text { Sedangkan bentuk "caping" dapat } \\
\text { dikaitkan dengan bangun ruang } \\
\text { kerucut. }\end{array}$ & $\begin{array}{l}\text { karakteristik tumbuhan dikotil } \\
\text { dan monokotil, serta cara } \\
\text { perkembangbiakannya }\end{array}$ \\
\hline & & Gambar 4. Botol jamu & Gambar 5. Tanaman obat \\
\hline 4. & $\begin{array}{l}\text { Sistem } \\
\text { bercocok }\end{array}$ & $\begin{array}{l}\text { Besaran dan pengukuran (Materi } \\
\text { kelas } 3 \text { tema } 6 \text { dan } 7 \text { ) }\end{array}$ & $\begin{array}{l}\text { Perubahan musim (Materi kelas } \\
3 \text { Tema } 3 \text { Subtema } 3 \text { ) dan }\end{array}$ \\
\hline & $\begin{array}{l}\text { tanam } \\
\text { masyarakat } \\
\text { jawa }\end{array}$ & $\begin{array}{l}\text { Bentuk sawah dapat dikaitkan } \\
\text { dengan materi satuan panjang dan } \\
\text { luas. Debit air dapat dikaitkan } \\
\text { dengan materi satuan volume. } \\
\text { Beras dan panen dapat dikaitkan } \\
\text { dengan satuan berat. }\end{array}$ & $\begin{array}{l}\text { ekosistem (Materi Kelas } 5 \text { Tema } \\
5 \text { ) } \\
\text { Pola dan waktu bercocok } \\
\text { tanamdapat dikaitkan dengan } \\
\text { musim, sedangkan komponen } \\
\text { biotik dan abiotik di sawah dapat } \\
\text { dikaitkan dengan materi } \\
\text { ekosistem. }\end{array}$ \\
\hline
\end{tabular}

Penanaman karakter pada anak juga didukung oleh budaya yang ada di lingkungan. Surakarta merupakan salah satu kota yang sarat dengan budaya Jawa yang semestinya dijaga dan dilestarikan. Pemahaman terhadap kearifan lokal sebagai nilai-nilai budaya luhur bangsa dapat dimanfaatkan sebagai sumber pembentukan karakter dan meningkatkan prestasi belajar siswa. Pengabdian ini merupakan salah satu keberlanjutan dari hasil penelitian yang mengusung tema tentang media MAS NOVEL (Math and Science Fotonovela) merupakan komik yang diarahkan pada tema kearifan lokal Surakarta pada muatan Matematika dan IPA di SD. (Prihastari \& Widyaningrum, 2018). Luaran yang dihasilkan dalam pengabdian ini adalah guru-guru memiliki pemahaman tentang budaya lokal yang dapat diintegrasikan dalam pembelajaran Matematika dan IPA dan hasil analisis pemetaan materi ajar yang terintegrasi Etnomathscience dalam pembelajaran Kurikulum 2013.

\section{METODE}

Pelaksanaan kegiatan pengabdian kepada masyarakat ini meliputi:

a. Tahap pendahuluan, pada tahap ini akan dipersiapkan surat ijin dengan pihak terkait, mempersiapkan tempat pelatihan, mempersiapkan materi, alat dan bahan.

b. Tahap sosialisasi dan audiensi, tahap ini dilakukan dengan cara mengumpulkan guru-guru SDN Prawit I No. 69 dan diberikan penjelasan mengenai budaya lokal kota Surakarta yang dapat diintegrasikan ke dalam materi ajar khususnya pada mata pelajaran Matematika dan IPA.

c. Tahap pelaksanaan kegiatan pelatihan, tahap ini dilakukan dengan metode ceramah partisipatif, interaktif, dan dialogis. Sehingga peserta pelatihan dapat dengan mudah memahami dan menerapkannya dalam menganalisis materi ajar yang dapat dikaitkan dengan budaya lokal setempat sesuai dengan kelas yang diampu oleh masing-masing guru. Setelah guru-guru dapat memetakan materi yang bisa dikaitkan dengan budaya lokal, guru juga diberikan sosialisasi cara menyusun bahan ajar yang dapat digunakan untuk mengajarkan 
materi yang terintegrasi dengan budaya. Membuat bahan ajar secara mandiri akan mempermudah guru dalam pelaksanaan belajar mengajar. Proses pelaksanaan pengabdian dilakukan dengan metode ceramah, tanya jawab, diskusi, dan praktek secara langsung.

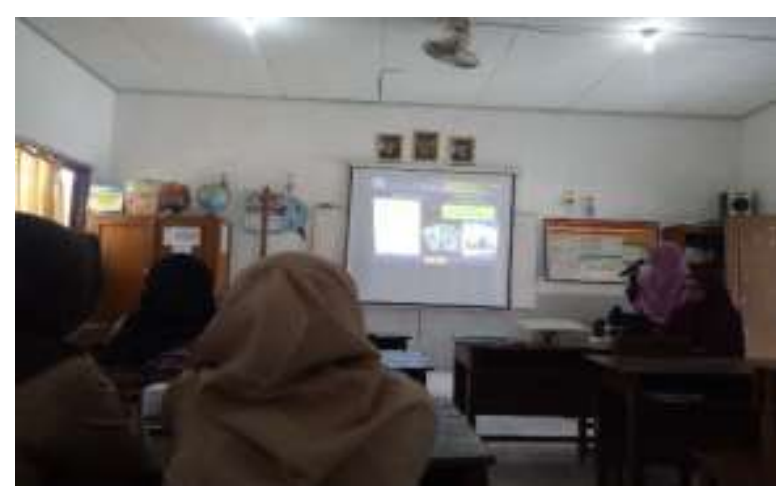

(a)

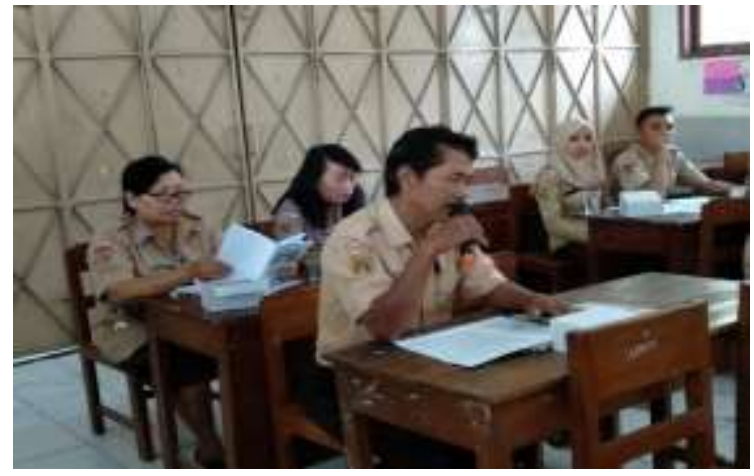

(b)

Gambar 7. Sosialisasi dan audiensi (a), diskusi dan praktek (b)

d. Tahap evaluasi akhir, mengevaluasi kegiatan sosialisasi etnomathscience dalam pembelajaran di SD yang mengintegrasikan pembelajaran matematika, IPA, dan budaya.

\section{HASIL DAN PEMBAHASAN}

Hasil yang dicapai dari kegiatan pengabdian masyarakat ini adalah meningkatnya kemampuan dan keterampilan guru SDN Prawit I No.69 Surakarta dalam memetakan materi pembelajaran yang dapat dikaitkan dengan budaya lokal. Selain itu, dengan adanya pemetaan materi akan mempermudah bagi guru dalam pembuatan perangkat pembelajaran serta pemnyusunan bahan ajar yang sesuai dengan budaya lokal yang akan diintegrasikan dalam pembelajaran. Selain kearifan lokal tentang batik Laweyan, Pasar Gede, tanaman obat, dan system bercocok tanam, beberapa kearifan lokal lain yang diintegrasikan oleh guru berkaitan dengan Taman Cerdas Nusukan, tumpeng, leker, alat musik gamelan, dan Pasar Nusukan. Materi Matematika dan IPA yang diintegrasikan dapat dipetakan pada Tabel 2 berikut.

Tabel 2. Hasil pemetaan materi oleh guru

\begin{tabular}{llll}
\hline No. & \multicolumn{1}{c}{ Kearifan Lokal } & \multicolumn{1}{c}{ Matematika } & \multicolumn{1}{c}{ IPA } \\
\hline 1. & $\begin{array}{l}\text { Taman Cerdas } \\
\text { Nusukan }\end{array}$ & Bangun datar dan bangun ruang & $\begin{array}{l}\text { Pengelolaan sampah } \\
\text { Ekosistem }\end{array}$ \\
2. & Tumpeng & Bangun ruang & Zat gizi pada makanan \\
3. & Leker & Bangun datar & Zat gizi pada makanan \\
4. & Alat musik gamelan & Bangun datar dan bangun ruang & Bunyi \\
5 & Pasar Nusukan & Bangun datar dan bangun ruang & Limbah \\
6 & Tarian daerah & Bilangan & Sistem Gerak Manusia \\
\hline
\end{tabular}

Hal tersebut menunjukkan bahwa guru-guru sudah memahami budaya lokal yang akan diintegrasikan dengan materi Matematika dan IPA. Sebagai contoh untuk Taman Cerdas Nusukan, dapat dikaitkan dengan materi bangun datar dan bangun ruang karena terdapat bentuk-bentuk 
struktur bangunan maupun fasilitas yang menyerupai bangun datar dan bangun ruang. Untuk materi IPA dapat dikaitkan dengan ekosistem dan pengelolaan sampah.

Pembangunan Taman Cerdas di Surakarta mempunyai tujuan untuk memberikan fasilitas umum bagi kegiatan bermain, berinteraksi dan belajar untuk anak-anak, serta untuk memanfaatkan aset tanah pemerintah yang belum terolah. Sedangkan sasaran Taman Cerdas itu sendiri adalah untuk masyarakat yang tidak mampu di sekitar lokasi. Taman Cerdas dapat dimanfaatkan khususnya untuk anak-anak marginal dan membutuhkan tempat untuk mendapatkan pengetahuan, pengembangan bakat, keterampilan, membaca, ruang kreasi seni, pengenalan teknologi informasi, tempat bermain, tempat rekreasi dan tempat untuk beradaptasi dengan lingkungannya (Sari, Kusumastuti, \& Putri, 2017). Lokasi taman bermain yang dipilih berada di depan sekolah dan berada satu lokasi dengan pondok baca sehingga diharapkan dengan adanya lokasi yang terintegrasi seperti ini memberi peningkatan nilai pada masing-masing fungsi ruang tersebut (Hantono, Ashadi, Purwantinasning, Nur'aini, \& Sari, 2020).

Untuk tumpeng dan kue leker yang termasuk makanan khas Surakarta, dapat dikaitkan dengan materi bangun datar dan zat gizi pada makanan yang dikaitkan dengan filosofi tumpeng tersebut. Menurut Endaswara (2003) tumpeng merupakan nasi putih yang dibentuk kerucut, yang penyajiannya dilengkapi dengan lauk pauk. Di dalam masyarakat Jawa, tumpeng berarti "metua dalan kang lempeng." Dalam hal ini yang dimaksud adalah "lewatlah jalan yang lurus," yaitu jalan yang dibawa oleh Rasulullah, yaitu agama Islam. Kedua, urap dalam bahasa Jawa sering disebut dengan gudhangan atau kuluban. Keduanya adalah lauk yang terbuat dari sayuran yang direbus kemudian dicampur dengan kelapa parut yang berbumbu. Gudhangan bermakna harapan untuk hidup bahagia. Ketiga, kering tempe sebagai lambang kesederhanaan dan kesahajaan. Keempat, sambel goreng kentang melambangkan kegairahan hidup yang diwarnai dengan rasa pedas, tetapi sedap dan nikmat. Kelima, ayam dhekem aatau ingkung yang dimasak utuh. Oleh masyarakat Jawa, ingkung diartikan sebagai "enggala jungkung" dimaksudkan agar bersegera bersujud atau beribadah sepenuhnya kepada Allah. Orang Jawa juga memaknai ingkung dengan "enggala manekung," yaitu bersegeralah berdzikir kepada Allah. Dengan demikian, ingkung bagi masyarakat Jawa adalah ajakan untuk segera beribadah sepenuhnya kepada Allah dengan menjalankan sholat dan berdzikir. Keenam Gesek atau ikan kering goreng menandai bahwa daerah yang bersangkutan adalah daerah penghasil ikan, yaitu di daerah pesisir (Indrahti, Maziyah, \& Alamsyah, 2017).

Berdasarkan evaluasi dan simulasi pada pelatihan dari kegiatan pengabdian masyarakat dapat diketahui bahwa dengan adanya pelatihan maka guru menjadi terampil memetakan materi ajar yang akan diintegrasikan dengan budaya lokal. Selain itu, program pengabdian yang dipaparkan menambah wawasan bagi guru untuk menyusun bahan ajar secara mandiri agar proses pembelajaran mampu berjalan dengan efektif. Selain pemetaan materi, guru-guru juga dibekali dengan teknik menyusun bahan ajar secara mandiri dan diberikan contoh media ajar yang telah mengintegrasikan kearifan lokal dengan materi pembelajaran. Hal tersebut dilakukan agar guru-guru termotivasi dalam mengembangkan bahan ajar dan media yang inovatif untuk mengenalkan budaya lokal kepada siswa tanpa menghilangkan unsur-unsur materi pembelajaran pokok di sekolah.

\section{KESIMPULAN}

Kegiatan pengabdian kepada masyarakat bermanfaat bagi guru sasaran karena setelah mengikuti kegiatan tersebut guru dapat memetakan materi yang akan diintegrasikan dengan budaya lokal dan merumuskan filosofi yang akan diintegrasikan dalam pembelajaran Matematika dan IPA. Sosialisasi penyusunan bahan ajar membantu guru untuk mengetahui teknik dan format dalam menyusun bahan ajar secara mandiri yang disesuaikan dengan hasil pemetaan materi budaya lokal. Hasil dari kegiatan pengabdian kepada masyarakat yang telah dilakukan yaitu pemetaan materi kearifan lokal Matematika dan IPA serta bahan ajar terintegrasi dengan kearifan lokal di Surakarta. 


\section{UCAPAN TERIMA KASIH}

Pengabdian ini merupakan bagian dari program kerja yang didanai oleh Universitas Slamet Riyadi. Oleh karena itu, ucapan terimakasi disampaikan kepada pihak Universitas Slamet Riyadi, segenap warga SDN Prawit I No. 69, dan mahasiswa yang telah membantu dalam pelaksanaan pengabdian.

\section{DAFTAR PUSTAKA}

Ambalegin, Arianto, T., \& Azharman, Z. (2019). Kampung Tua Nongsa Sebagai Tujuan Wisata Berbasis Kearifan Lokal Budaya Melayu Batam. Dinamisia: Jurnal Pengabdian Kepada Masyarakat, 3(Juni). https://doi.org/10.31849/dinamisia.v3i2.2863.

Hadi, W.P., Sari, F.P., Sugiarto, A., Mawaddah, W. \& Arifin, S. (2019). Terasi Madura: Kajian Etnosains dalam Pembelajaran IPA untu Menumbuhkan Nilai Kearifan Lokal dan Karakter Siswa. Quantum: Jurnal Inovasi Pendidikan Sains, 10(1). 45-55. http://dx.doi.org/10.20527/quantum.v10i1.5877.

Hantono, D., Ashadi, Purwantiasning, A. W., Anisa, Nur'aini, R. D., \& Sari, Y. (2020). Pengadaan Taman Bermain Anak Untuk Peningkatan Kualitas Pendidikan di Madrasah Ibtidaiyah Nurul Huda II Dusun Gunung Leutik Kabupaten Bogor. Dinamisia: Jurnal Pengabdian Kepada Masyarakat, 4(2), 236-241. https://doi.org/10.31849/dinamisia.v4i2.3897

Indrahti, S., Maziyah, S. \& Alamsyah. (2017). Ragam Kuliner Sesaji Upacara Tradisi di Kabupaten Jepara. Jurnal Sejarah Citra Lekha, 2(1), 61-74. https://doi.org/10.14710/jscl.v2i1.14547

Kemendikbud. (2016). Peringkat dan Capaian PISA Indonesia Mengalami Peningkatan. Jakarta: Biro Komunikasi dan Layanan Masyarakat Kemendikbud. Diakses 13 September 2020, dari https://www.kemdikbud.go.id/main/blog/2016.

Prihastari, E \& Widyaningrum, R. (2018). Pengembangan MAS NOVEL Berbasis Etnomatsains untuk Menanamkan Sikap Peduli Lingkungan Siswa Sekolah Dasar. Jurnal Profesi Pendidikan Dasar, 5(2), 167-176. https://doi.org/10.23917/ppd.v1i2.6944.

Sari, R.P., Kusumastuti, \& Putri, R.A. (2017). Kesesuaian Taman Cerdas Sebagai Ruang Publik Skala Pelayanan Kelurahan Terhadap Konsep Kota Layak Anak. Region: Jurnal Pembagunan Wilayah dan Perencanaan Partisipatif, 12(1), 71-82. https://doi.org/10.20961/region.v12i1.12116

Sunandar, M. A. (2017). Pembelajaran Matematika SMK Bernuansa Etnomatematika. PRISMA, Prosiding Seminar Nasional Matematika, 95-105. Retrieved from https://journal.unnes.ac.id/sju/index.php/prisma/article/view/21622.

Wagiran. (2011). Pengembangan Model Pendidikan Kearifan Lokal Dalam Mendukung Visi Pembangunan Provinsi Daerah Istimewa Yogyakarta 2020 (Tahun Kedua). Jurnal Penelitian Dan Pengembangan, 3 (5), 85-100.

Wahyuni, A., Aji, A., Tias, W., \& Sani, B. (2013). Peran Etnomatematika dalam Membangun Karakter Bangsa. Prosiding Seminar Nasional Matematika dan Pendidikan Matematika FKIP UNY, 114118. https://eprints.uny.ac.id/10738/1/P\%20-\%2015.pdf.

Widyaningrum, R. (2018). Analisis Kebutuhan Pengembangan Model Pembelajaran Berbasis Etnosains untuk Meningkatkan Kualitas Pembelajaran IPA dan Menanamkan Nilai Kearifan Lokal di Sekolah Dasar. Widya Wacana: Jurnal Ilmiah, 13(2), 26-32. http://dx.doi.org/10.33061/ww.v13i2.2257. 